\title{
DIDACTICS OF THE MILITARY SPECIALTY - PEDAGOGIC PROCESS WITH MAJOR IMPLICATIONS IN THE CURRICULAR ARCHITECTURE OF MILITARY LEADERS' TRAINING
}

\author{
Robert STĂNCIULESCU*, Elvira BELDIMAN** \\ *“Nicolae Bălcescu" Land Forces Academy, Sibiu, Romania \\ **Bucharest Bar, Romania \\ rstanciulescu@armyacademy.ro., avoelvira@yahoo.co.uk
}

\begin{abstract}
Didactics is, in the etymological sense, the science of learning, a science that has evolved over time under the influence of the maturing of the other sciences of education and as a result of relations with other scientific fields. Through the common subject (the learning process, training through the learning process), didactics is associated with the training theory.
\end{abstract}

Keywords: didactics, leader, education, training, functions

\section{Introduction}

In the last decades, didactics began to lose the traditional sense of theoretical and practical foundation of the teachinglearning process, receiving a new meaning (developed by the US educational context), that of empowering the teaching staff to apply the laws and rules of teaching in line with its contents and strategies (Doyle and Westbury, 1992)[1]. Miron Ionescu presents, in a nutshell, the most important contributions to the development of the theory and practice of training[2]:development of a working model by J. A. Comenius and its description in Didactica Magna (the first pedagogical system, the first theoretical model on education and instructional issues); - development of a pedagogical system based on a conventional model by J. F. Herbart and his disciples (based on a unique structure of lessons; the formal steps of the lesson); crystallization of a global pedagogical conception through the contributions of $\mathrm{J}$. Dewey, E. Meumann, M. Montessori (introduction of new research techniques - mathematical experimentation and computation - which facilitated the establishment of causal relationships between different educational phenomena and pedagogical laws);- development of new training models: B.F. Skinner, J. Piaget, P.I. Galperin (substantiating the training models on specific theories of learning); - development of a working model by J.S. Bruner (development of an explicit learning theory).

\section{Didactics - branch of the sciences of education}

The foundation of didactics as a theory of training involves passing three distinct stages, extended, according to current interpretations, to the level of curriculum theory[3]: Traditional didactics stage; Modern didactics stage; Postmodern didactics stage.

Wincenty Okón considers that the purpose of didactics is: a) to analyze: the aims and content of training, the educational process and its principles and b) to make known: the teaching methods and means, the 
organization of education, the planning of teaching, the personality of the instructor [4]. Studying the process of education in what is essential and general, general didactics orients the methodologies in discovering and solving specific problems, related to the teaching and learning of knowledge and skills specific to a teaching subject. Didactics is the theoretical basis of methodology. This does not mean that methodology would only take the theses and the conclusions of didactics to concretize them to a subject of study. As a special theory, didactics deals with the relationship between teaching and learning in a field of phenomena circumscribed by the internal logic of the subject matter, explaining the pedagogical process that is constituted, and prescribing ways of its operation[5]. If didactics provides the theoretical basis of methodologies, they also provide concrete material for the generalizations that are developed in didactics. The relationship between general didactics and special didactics is one of mutual influence. Some theorists reinterpret its traditional sense: "The relationship between special and general didactics can be highly operative by learning the practical and instrumental theories. There is no contradiction and no hierarchical relationship between general didactics and special didactics. Their relationship is rather of substance and form and it depends on the central point of interest: general or individual'"[6].

\subsection{The role of didactic (methodological) knowledge in the training of military leaders}

Sometimes it is suggested that there can be no systematic scientific training in the field of teaching a subject, that teaching is a strictly personal matter and that each military leader has his or her own teaching method. Other times, it is claimed that thoroughly mastering the content of a scientific discipline fully ensures the effectiveness of teaching. The above statements can find countless counterevidence in the instructional-educational reality (to which we will not refer), and they cause great harm in the practice of military leader (instructor) training. Given the fact that the requirements of a science-based activity are necessary in all sectors of life, it appears almost paradoxical that the training of the future "builder" of human personalities should be left to chance and be realized, to the extent that it is done, only on the basis of self-training, empirically. Intuition, common sense can lead to the training of practitioners, but in no case to the training of leaders who meet the demands of modern education. In order to prove the usefulness of systematic and permanent training in the field of didactics, it is necessary to analyze, even briefly, at least two problems:

a) the relationship between specialized training, didactic training and the personality of the leader

b) the role of the personality of the leader in the current stage

Undoubtedly, the thorough knowledge of the specialty is a postulate in the discussion about the professional status of the military leader. No didactics can prevent the poorly prepared teacher (the instructor) from putting himself or herself into a compromising situations and, worst of all, from compromising sometimes the object he or she represents. At the same time, practice has shown that some very welltrained people fail to convey what they know, fail to capture interest and communicate with the trainees, a situation created by the ignorance of pedagogical and psychological issues or of some methodical aspects. Selecting information, organizing it into a certain structure, subordinating it to knowledge and training goals are some of the most important methodological issues that cannot be solved by a poor military leader, and cannot be solved exclusively by knowing the specialty either. With the increasing primacy of training and interdiscipline in the educational-training process in the army, and the socially motivated need to train professionals with a soft and creative thinking able to adapt to 
the challenges of the "third wave" society, the specialty of the military leader becomes a tool for training a professional. Of course, the tool must be solid enough to increase work efficiency. But "the purpose" remains, however, in the field of psycho-pedagogical and methodological issues. The students, during teaching practice stage, and the leaders in the first years of practicing the profession, classify in hierarchical order, among the greatest difficulties encountered, the methodical ones, such as:

a) detailed knowledge of specialty problems without having an overview of the specific subjects;

b)difficulties in making a real and motivated selection of the information they have about one topic or another and the need to handle psycho-pedagogical criteria;

c) making the teaching-learning process accessible without lowering exigencies;

d) correlating the knowledge in the process of forming the new notions.

This is significant in order to emphasize the importance of a permanent methodical approach, and it proves that some investigations are necessary.

Accepting that methodologies in general and, thus the didactics of specialized training with the subunits, are part of the system of pedagogical sciences, we also implicitly mention the relations between methodology on the one hand and general pedagogy (military pedagogy) on the other hand, between methodology and other scientific processes of the system. The relationships that are established are multilateral and complex. The correlation between the pedagogical processes is presented as a multidimensional network within which particular sciences are defined and developed. In spite of the enormous differentiation, of the emergence of new branches and intermediary branches, the whole system of pedagogical sciences, as well as the entire contemporary science, has an internal gnoseological unity, and progresses in direct or mediated dependence on the needs of the practice. Didactics, for example, benefits from the acquisition of all pedagogical sciences and is part of the joint creative effort with its own results, with its specific characteristics. We also believe that although they can be included in a group, the didactics can legitimately claim their status as standalone processes, whose main distinguishing mark is given by the specifics of the knowledge covered by the training process.

\subsection{Didactics - the pedagogy of military specialty}

The history of any methodology is indisputably related to the history of the establishment and development of a training process, and ultimately to the history of building the whole body of knowledge that can serve as a teaching object. By virtue of their reporting to distinct fields of human knowledge, the different methodologies differ fundamentally from each other. The issue of didactics of specialized instruction with subunits has few common points with physics teaching didactics, and mathematics teaching didactics will not be able to use the logical schema of biology teaching didactics. The differences are determined by the cognitive specificity, the functions and the internal logic of the scientific process. Didactics differ from each other, because within these processes there are special problems, special rhythms of accumulation of knowledge and skill development, typical means of obtaining information, and various relationships with other educational processes. The content of the different methodologies is determined, first of all, by the content of their respective processes, as well as by their relationship with other processes. The didactics of the military specialty, in this case, is a complex process that, besides the specific problems of the technique and apparatus, integrates the cognitive, psychomotor and emotional capacities acquired in other training processes. As a result, the content of the military specialty has characteristics which are determined ultimately by the typical particularities of the training. This is made even clearer if we take into account the 
ultimate goal of didactics - to optimize the instructive-educational process. In the didactics of the specialty (methodology), which is a scientific process that focuses on the applicative and normative character, we can distinguish several levels as follows: a general level, where the central system of specific categories is formed, establishes the main relations with pedagogy, psychology, logic etc. and emphasizes its lawfulness; a particular level at which, based on the symbiosis with the respective scientific processes, the main content of the different methodologies is achieved; and, finally, the level at which special problems of the knowledge subgroups are addressed, at which the pace of change is faster. The dynamics of this level depends on a number of social and individual factors, among which we should mention the cultural and scientific level of the macro and micro group, the type of motivation, the existing intellectual work skills, the group and individual working style, the typical physical and mental state of the subjects, the personality traits of the person in charge with the instructive-educational process, etc. That is why methodological "recipes" have a very limited sphere of application, and, if used indiscriminately, they can lead to unwanted effects even by those who develop them. At the same time, they do not stimulate the creative capacity of an educator or the full manifestation of the personality of the trainee. Of course, methodical guidelines are useful, helping to solve a situation. In order to introduce these guidelines into the respective didactic heritage, such indications must be validated by research and subjected to a theoretical approach. Didactics finds its content through the investigation of the scientific process, respectively from the point of view of the instructive-educational objectives.

Some authors rightly define the didactics of the specialty as the strategy by which, within the process of training, aspects such as the content of a given process, its meaning for practice, its relations with other scientific processes, and its educational importance are revealed. It is indisputable that specialty didactics finds its reason to exist only to the extent to which it fulfills the tasks specific to a certain field of scientific knowledge. Formulating and solving of such tasks, in parallel with the evolution of the knowledge in the field, remains an ongoing problem. The successive stages of the process create a new meaning and a new sense for the entire body of knowledge, forcing it to constantly redefine the domain and its relations with other areas of knowledge. In order to fulfill its purpose, the didactics of the specialty carries out a continuous research of the specific field from the perspective of the general instructive-educational objectives. The didactics of the specialty follows and translates into its own terms the movement within the knowledge system.

\subsection{The functions of military specialty didactics}

In the last decades, the words "method" and "methodical" have been used up to saturation in the specialty literature in various fields, in journalism and in everyday speech. Their undifferentiated use has created ambiguities which have altered the original, authentic meaning of the terms. Beyond the constant need for science to redefine its notions in relation to the advances of knowledge, it becomes clear, if we analyze the usual sense in which these words are used, that there is a major imperative of modern thinking. In the current speech, "having a method," "being methodical", "mastering the methodology of a paper" means working systematically and having the strategy necessary for achieving a determined goal. Modern thinking is predominantly economical and practical and, therefore, it does not have great variations from the simple the goal-strategy scheme. And, as we have seen, methodologies are all about finding the best strategies to improve educational practice, to optimize one of the processes through which society ensures its continuity and progress. In a very conventional way, we can distinguish between the theoretical and 
practical functions of didactics in general and the didactics of specialized instruction, with subunits in particular. Didactics is a science of practical social action, which justifies its research efforts only in so far as it contributes to the optimization of the studied processes. The didactics of a subject (study) really exists only when it has an active role in fulfilling the content of the scientific process, respectively in the training activity, when it contributes to the revealing of the educational values of the subject, when it facilitates the passing from the scientific fact, to conviction and, hence, to action. Therefore, the theoretical functions of didactics have immediate practical implications, and its practical functions involve a theoretical approach. Not every approach to the process of learning a body of knowledge leads to improved solutions, and not every solution can be validated. Only an informed scientific approach performed with appropriate means of control and investigation gives rise to a real improvement in the teaching-learning process of a particular discipline.

As a scientific process, didactics is enriched through the continuous study and perfection of the current instructive-educational activity. The research functions of didactics are both theoretical and practical at the same time, all the more so since, nowadays, research is not only done by researchers but also by all those who want to scientifically substantiate their actions. In the instructiveeducational process, most Land Force leaders are convinced of this need. The unity between the theoretical and the practical aspects of the didactic functions of the specialized instruction is emphasized not only by the analysis of didactics in its quality as a scientific process, but also by emphasizing its role as an object of instruction. As part of the educational plans of the "Nicolae Balcescu" Land Forces Academy and of those of the Weapons Training Centers, after going through the major specialty subjects, the military specialty didactics has the role to perform a theoretical reconstruction of the knowledge accumulated by the military students and, obviously by the military-trained leader, aiming at certain concrete instructiveeducational tasks. Didactics also aims at suggesting to the future military leaders the problems to be solved, as well as the possible research ways and to provide them with the existing solutions, the methods and the didactic techniques known and verified in the current activity. In addition, in accomplishing the tasks, in the didactics of the military specialty, the two sides, theoretical and practical, are inextricably linked. The former raises the methodical problems of the respective discipline/subject of education (instruction). The latter presents the didactics of teaching, the systematic way in which the military students and the military leaders are trained to learn and to love this discipline/subject. Together, the two sides express the function with which teaching, along with pedagogical practice, provides young would-be military leaders the necessary methods and techniques after graduation. The competence of the future military leader of the Land Forces will be achieved through the procedural confluence of "knowing," "doing," and "being." "Knowing" is the imperative seal of knowledge. In its form, the agent of action becomes an expanding informational universe, being "pressed", and assuming its role of selectively and critically taking over the existing information and creating new information, communicating, distributing and effectively using information in transformative actions. By the last aspects pertaining to the "know" imperative, the passage into the space of the imperative " $d o "$ is already visible, the norm of all action being effective action. As a result, "to be" comprises the agent's own being, the matrix of its expression in "sets" of concrete acts, "roles" and social "functions". On the stage of "being", the agent of action reaches the fullness of "is." The triple hypostasis of the human action agent in "knowing," "doing," and "being," 
engages an essential prerequisite for the intrinsic nature of competence. It will feed and express itself not only from and not only through knowledge, the abilities of transformation or the moral-existential "texture" of the agent of action. Competence will mean all of these at once and together.

\section{Conclusions}

As a scientific process, didactics is enriched through the continuous study and improvement of the current instructiveeducational activity. The research functions of the didactics are both theoretical and practical especially that, nowadays, the research is done not only by researchers but also by all those who want to scientifically substantiate their actions. In the instructiveeducational process, most military leaders in the Land Forces are convinced of this necessity.

\section{References}

[1] Iucu B. R., Instruirea şcolară. Perspective teoretice şi aplicative, Iaşi, Editura Polirom, 2001,p. 10.

[2] Ionescu, M., Radu, I. (coord.), Didactica modernă, Ediţia a II-a, revizuită, Cluj-Napoca, Editura Dacia, 2001 p. 25.

[3] Cristea S., Pedagogie Generală. Managementul Educaţiei, Bucureşti, Editura Didactică şi Pedagogică, R.A. 1996, p. 98.

[4] Ionescu, M., Radu, I. (coord.), op.cit., p. 20.

[5] Nicola Ioan, Tratat de pedagogie şcolară, Bucureşti, Editura Didactică şi Pedagogică, R. A., 1996, p. 273.

[6] B. Iucu Romiţă, Instruirea şcolară. Perspective teoretice şi aplicative, Iaşi, Editura Polirom, 2001, p. 19. 